\title{
Korištenje ketogene dijete u onkoloških pacijenata u maloj praksi
}

\author{
D. Brozici, H. Hajdin, N. Maćešić, M. Samardžija i H. Valpotić
}

\section{Sažetak}

Istraživanja ukazuju da je metabolizam stanica tumora obilježen promjenama $\mathrm{u}$ proizvodnji energije putem oksidativne fosforilacije i fermentacije te se smatra kako je moguće kontrolirati rast i razvoj tumora promjenom energetskog supstrata. Tumorske stanice pokazuju povećanu potrošnju glukoze, čak i u aerobnim uvjetima, što se događa zbog poremećaja u mitohondrijskom staničnom disanju pri čemu pojačana glikoliza predstavlja kompenzatorni odgovor. Stoga bi promjene $u$ prehrani, poput ketogene dijete $\mathrm{s}$ visokim udjelom masti, umjerenim udjelom bjelančevina i niskim udjelom ugljikohidrata, koje potiču oksidativni metabolizam mitohondrija, istovremeno limitirajući potrošnju glukoze, predstavljale mogući nutritivni pristup selektivnom metaboličkom stresu tumorskih stanica. Iako je primjena ketogene dijete, kao potporne terapije tumora opetovano dokazana $u$ humanim istraživanjima do danas nije

provedeno istraživanje koje bi potvrdilo pozitivne učinke u pasa i mačaka s tumorima. No, korištenje MCT dijete u pasa s epilepsijom dalo je obećavajuće rezultate. Metaboličke specifičnosti prisutne u pasa i mačaka poput učinkovitog iskorištavanja ketogenih tijela od strane perifernih tkiva te prilagodba visokom udjelu masti u obroku, pod uvjetom da je zadovoljen glukoneogenetski kapacitet, ukazuju da postoje temelji za primjenu ketogene dijete $\mathrm{u}$ onkoloških pacijenata, no bez istraživanja koje bi navedeno potvrdila nije moguće tvrditi kako je korištenje ketogene dijete bez rizika. Prema trenutnim smjernicama, pri izradi prehrambenog plana kod onkoloških pacijenata ključno je prilagoditi oblik hranidbenog režima svakom pacijentu pojedinačno, uzimajući pritom u obzir kliničku sliku, prognozu i prisutnost ostalih patologija koje će uvjetovati prilagodbu obroka.

Ključne riječi: ketogena dijeta, tumori, pas, mačka

\section{Uvod}

Tumori su jedan od najčešćih uzroka uginuća pasa i mačaka (Snyder i sur., 2004., Bonnet i sur., 2005.). Raspon u populaciji pasa iznosi od $18-23 \%$ s

većom učestalosti u ženki (Egenvall i sur., 2005.). Pojava tumora u pasa i mačaka često dovodi do promjene unosa hrane, hranidbenog statusa i

Dr. sc. Diana BROZIĆ* (dopisni autor, e-mail: diana.brozic@vef.hr), dr. med. vet., docentica, dr. sc. Hrvoje VALPOTIĆ, dr. med. vet., izvanredni profesor, dr. sc. Nino MAĆEŚIĆ, dr. med. vet., izvanredni profesor, dr. sc. Marko SAMARDŽIJA, dr. med. vet., redoviti profesor, Veterinarski fakultet Sveučilišta u Zagrebu, Hrvatska; Helena HAJDIN, dr. med. vet., Varaždin, Hrvatska 
kondicije, stoga se onkološki pacijenti smatraju ciljnom skupinom korisnika individualno prilagođene nutritivne potpore. Pod pojmom ketogene dijete podrazumijevamo unos visokog udjela masti, umjerenog udjela proteina te niskog udjela ugljikohidrata, pri čemu dolazi do smanjenja metabolizma ugljikohidrata i proteina, s posljedičnim iscrpljivanjem glikogena $u$ jetri i skeletnoj muskulaturi te povećanja metabolizma masti čime se ograničava opskrba glukozom, istovremeno osiguravajući adekvatne količine energetskih supstrata $\mathrm{u}$ obliku masti za tvorbu ketonskih tijela. Istraživanja ukazuju kako je bitna karakteristika tumora njihova prilagodba u proizvodnji energije putem oksidativne fosforilacije i fermentacije te se smatra kako je moguće kontrolirati rast i razvoj tumora promjenom energetskog supstrata, točnije povećanim iskorištavanjem ketonskih tijela $\mathrm{u}$ oksidativnoj fosforilaciji te smanjenim iskorištavanjem glukoze i glutamina u fermentaciji i putem sinteze laktata (Seyfried i sur., 2014.). Budući da se metabolizam između vrsta razlikuje, nužno je prilagoditi i sam oblik metaboličke terapije, tj. ketogene dijete koja se koristi u liječenju onkoloških pacijenata (Seyfried i sur., 2014.). Stoga bi promjene u prehrani, poput ketogene dijete $s$ visokim udjelom masti i niskim udjelom ugljikohidrata, koje potiču oksidativni metabolizam mitohondrija, istovremeno limitirajući potrošnju glukoze, predstavljale mogući nutritivni pristup selektivnom metaboličkom stresu tumorskih stanica. Opisana su dva osnovna tipa ketogenih dijeta: ketogena dijeta na temelju dugolančanih triglicerida (engl. long chain triglycerides, LCT) i ketogena dijeta na temelju srednjelančanih triglicerida (engl. medium chain triglycerides, MCT), od kojih je MCT dijeta jedina koja se primjenjuje $u$ veterinarskoj medicini dok je korištenje LCT dijete opisano tek $\mathrm{u}$ vidu mnogobrojnih znanstveno nepotvrđenih iskustava vlasnika koji su samoinicijativno koristili ovaj hranidbeni režim promoviran putem nerecenzirane literature: knjiga i članaka. Dodatno, primjena ketogene dijete u pasa i mačaka $\mathrm{u}$ vidu hranidbenog režima tijekom liječenja ili oporavka, u onkoloških pacijenata, u postojećoj veterinarskoj znanstvenoj literaturi nije opisana, za razliku od humane medicine gdje postoji znatan broj istraživanja koja ukazuju na primjenu $u$ onkološkom liječenju (Poff i sur., 2014.). Stoga je cilj ovog rada dati pregled dosadašnjih istraživanja iz područja dijetetike onkoloških pacijenata $\mathrm{u}$ veterinarskoj medicini, primjenu ketogene dijete $u$ navedenom slučaju i ukazati na moguće nedostatke ovakvog vida hranjenja u pasa i mačaka.

\section{Metabolizam ketonskih tijela}

Slobodne masne kiseline se $\mathrm{u}$ jetri metaboliziraju do acil-koenzim A, koji u mitohondrijima putem $\beta$-oksidacije prelazi u acetil koenzim A. Acetil koenzim A zatim ulazi u Krebsov ciklus pri čemu nastaje energija ili se pretvara $u$ ketonska tijela: acetoacetat, $\beta$-hidroksibutirat i aceton. Ketonska tijela se dalje krvlju i limfom transportiraju u razna tkiva te se u mozgu, srcu, mišićima i ostalim tkivima koriste kao izvor energije (El Bacha i sur., 2010.) (Slika 1.). U pasa, za razliku od ljudi i nakon dugoročnog posta ne dolazi do razvoja značajne ketonemije, a izlučivanje ketonskih tijela urinom ne prelazi više od 1 \% (De Bruijne i sur., 1981.). U odnosu na tjelesnu masu, razina pretvorbe ketonskih tijela tijekom noćnog posta dvostruko je veća u ljudi nego u pasa, dok je koncentracija ketonskih tijela najmanje deset puta veća u ljudi (De Bruijne i sur., 1981.). Spomenuti podatci upućuju na to da psi iskorištavaju ketonska tijela daleko učinkovitije od ljudi te je dokazano kako je niska koncentracija ketonskih tijela u pasa tijekom gladovanja posljedica 
učinkovitog perifernog iskorištavanja, a ne smanjene hepatičke proizvodnje (De Brujine i Van Den Brom, 1985.). Izrazita sklonost mačaka hepatičkoj lipidozi razlog je nemogućnosti provođenja istraživanja metabolizma ketonskih tijela uslijed gladovanja (Blanchard i sur., 2002.). Međutim, smatra se kako mačke, poput pasa, posjeduju učinkovite mehanizme iskorištavanja ketonskih tijela pod uvjetom da je glukoneogeni kapacitet zadovoljen. Smatra se da razina masti u obroku mačaka od 40$45 \%$ na bazi suhe tvari (ST), ako je razina bjelančevina prisutna $\mathrm{u}$ istom ili višem udjelu, može smatrati sigurnom zbog brze adaptacije metabolizma $u$ vidu korištenja masti kao primarnog energetskog supstrata bez negativnih posljedica: hipertrigliceridemija i hiperkolesterolemija (Lester i sur., 1999., Butterwick i sur., 2012.). Dodatno, obrok koji se sastojao od $29,9 \%$ sirove bjelančevine (SB) i 62,7 \% masti na bazi ST nije doveo do promjene $u$ razini glukoze, inzulina i leptina, iako je zabilježena značajno viša razina slobodnih masnih kiselina i triglicerida neposredno nakon obroka (Keller i sur., 2017.). No bitno je istaknuti kako su provedena istraživanja koristila obroke s visokim udjelom masti kroz relativno kratko razdoblje $(6,4$ i 1 tjedan), stoga je potrebno potvrditi sigurnost obroka s visokim udjelom masti u mačaka kroz istraživanja koja bi obuhvatila dulji vremenski period uz praćenje koncentracije ketonskih tijela u krvi i urinu. U mačaka je ustvrđeno kako razina ketonskih tijela u cirkulaciji ne prelazi razinu od $1 \mathrm{mmol} / \mathrm{L}$ ni nakon 4 tjedna gladovanja, ukoliko je u obroku dostatna koncentracija karnitina, što ukazuje na učinkovito iskorištanjanje ketonskih tijela kao energetskog supstrata od strane perifernih tkiva (Blanchard i sur., 2002.). Dodatno, u pasa i mačaka zabilježena je sposobnost održavanja normoglikemije i stabilne razine inzulina i u trenutcima kada masti postaju dominantan energetski supstrat uz optimalnu koncentraciju bjelančevina u obroku, pri čemu glukoneogeneza postaje dominantni metabolički put sinteze glukoze za periferna tkiva (Kronfeld i sur., 1977., De Bruijne i sur., 1981., Keller i sur., 2017.).

\section{Korištenje ketogene dijete kao potporne terapije}

$\mathrm{Na}$ temelju kliničkih iskustava, ketogena dijeta počela se primjenjivati sredinom 1990-ih godina, kao prihvatljiva alternativa u liječenju epilepsije kod djece koja ne reagiraju na druge oblike terapije (Neal i sur., 2008.). No u pasa i mačaka, moguća učinkovitost primjene ketogene dijete i dalje ostaje nepoznanicom. Mogući razlog otežanoj provedbi istraživanja učinka ketogene dijete na psima je činjenica da psi ne postaju lako ketotični zbog učinkovitog perifernog iskorištavanja ketonskih tijela (De Bruijne i Van Den Brom, 1985.). Primjena prekursora ketonskih tijela s ciljem izazivanja ketoze $\mathrm{u}$ pasa nije bila učinkovita budući da se prekursori očito iskoriste unutar nekoliko sati od same aplikacije (Puchowicz i sur., 2000.). Ipak istraživanja novijeg datuma ukazala su na obećavajuće rezultate kod primjene MCT dijete $u$ epileptičnih pasa (Law i sur., 2015.). Naime, ustvrđeno je kako je učestalost napadaja značajno manja kod pasa hranjenih MCT dijetom. Primjena MCT dijete rezultirala je i značajnim porastom $\beta$-hidroksibutirata $u$ krvi $u$ usporedbi s kontrolnim obrokom, pri čemu nije bilo značajnih promjena $u$ koncentraciji glukoze u krvi i tjelesne težine (Law i sur., 2015.). U mačaka nije zabilježeno korištenje ketogene dijete kroz znanstvena istraživanja. Dodatno, mačke su obvezni mesojedi čija se izvorna prehrana sastoji od obroka s visokim udjelom bjelančevina, umjerenim udjelom masti i niskim udjelom ugljikohidrata, stoga se metabolički oslanjaju na 


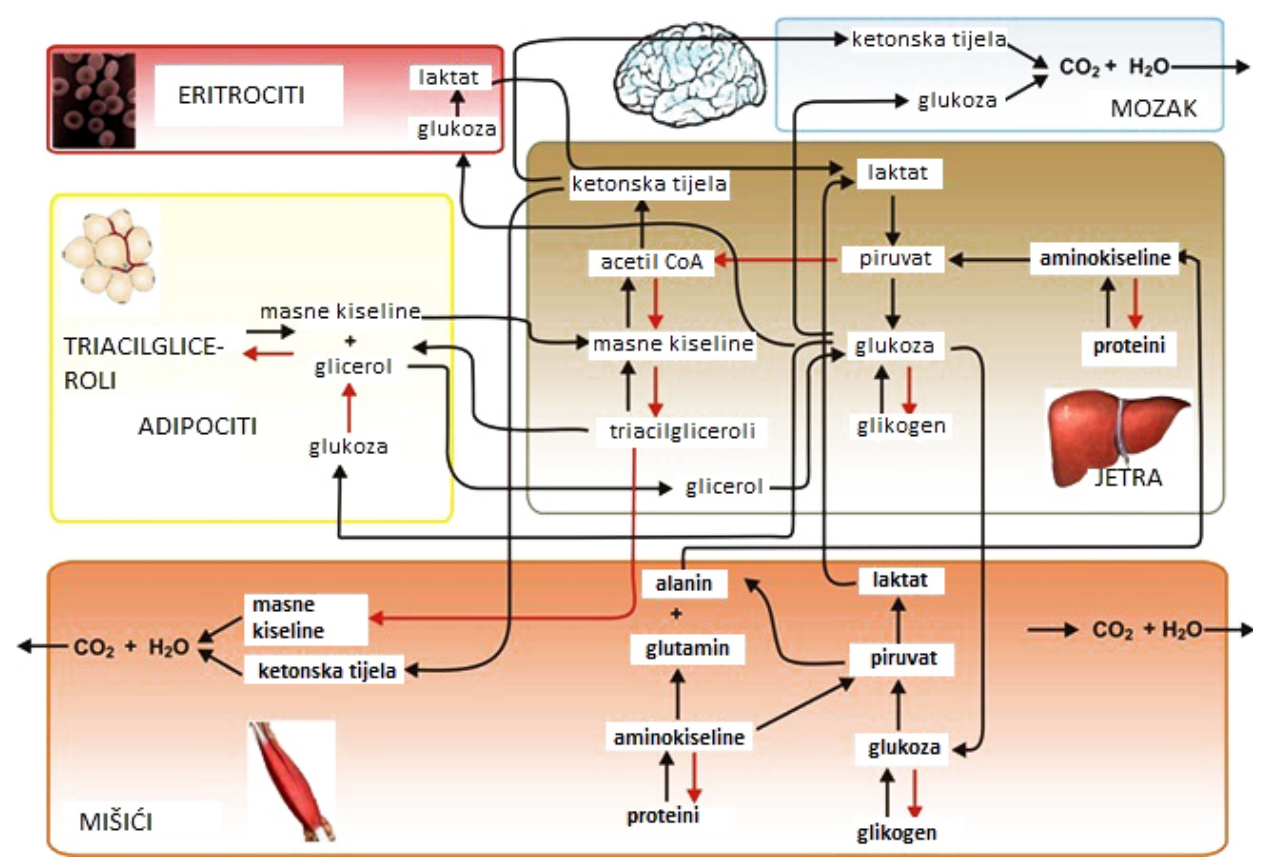

Slika 1. Kruženje ketonskih tijela u organizmu; prema: El Bacha i sur. (2010.).

glukoneogenezu kako bi sintetizirali dostatnu koncentraciju glukoze (Eisert, 2011.). Međutim, ustvrđeno je kako se mačke lako metabolički mogu prilagoditi znatno višem udjelu masti (37-47 \% na bazi ST) u obroku bez negativnih posljedica na homeostazu, uz uvjet da su potrebe za glukoneogenim kapacitetom i esencijalnim hranjivim tvarima zadovoljene (Lester i sur., 1999.). Međutim, dugotrajna primjena obroka s visokim udjelom masti kao i rizik od razvoja hepatičke lipidoze tijekom njegove primjene, u mačaka, nije istražena.

\section{Ketogena dijeta na temelju dugolančanih triglicerida}

Najčešće korištena ketogena dijeta $\mathrm{u}$ humanoj medicini temelji se na dugolančanim trigliceridima (LCT), a najčešće podrazumijeva unos metaboličke energije (ME) masti prema bjelančevi- nama i ugljikohidratima u omjeru 4:1, ili rijeđe u omjeru 3:1, 2:1 ili 1:1 (Westman i sur., 2008.). U pasa i mačaka se primjena ovog oblika ketogene dijete kao hranidbeni protokol u terapiji onkoloških pacijenata, koristi među pobornicima hranjenja pasa obrokom na bazi sirovog mesa te su zabilježena individualna pozitivna iskustva pri korištenju, pri čemu se koriste omjeri od 2:1 do 4:1 (udio ME od masti : bjelančevina i ugljikohidrata) pri čemu je udio ugljikohidrata prisutan u obliku sirove vlaknine u prosjeku od $2 \%-3 \%$, a lakoprobavljivih ugljikohidrata manje od $2 \%$, na bazi ST. Međutim, do danas nisu provedena znanstvena istraživanja koja bi navedene pozitivne učinke i potvrdila. Mogući razlog za navedeno je izrazito visok udio masti u obroku što u tehnološkom smislu proizvodnje ekstrudirane ili konzervirane hrane može predstavljati izazov. Dodatno, dokazano je kako visok udio masti uz smanjeni 
udio bjelančevina 28:60:9 (ugljikohidrati : masti : bjelančevine) može dovesti do visoke incidencije pankreatitisa i masne infiltracije jetre (Linsday i sur., 1948.). Međutim, navedeno istraživanje je koristilo obrok u kojem je udio bjelančevina niži od preporučenog, a protokol hranjenja temeljen je na obroku čija je energetska vrijednost bila dvostruko veća od preporučenih (NRC, 2006.). Nasuprot tome, istraživanje koje je pratilo biokemijske promjene tijekom rada pasa za vuču saonica pri čemu se koristio obrok koji nije sadržavao ugljikohidrate (ugljikohidrati, masti i bjelančevine u omjerima od 0,4:37:53 na bazi ST) nije zabilježilo negativne učinke takvog obroka na biokemijske pokazatelje, pri čemu psi nisu razvili znakove hipoglikemije, ketoze, uremije ili druge metaboličke poremećaja kada su bili hranjeni obrokom bez ugljikohidrata tijekom 9 tjedana (Kronfeld i sur., 1977.). Glukoneogenetski kapacitet pasa prilagođen obroku bez ugljikohidrata mora biti dostatan da se sinteza potrebne glukoze vrši iz prekursora poput aminokiselina i derivata glicerola iz hrane, čak i kada ukupna razina energetskog metabolizma dosegne razinu četiri puta veću od razine uzdržnih potreba, kao što je slučaj u provedenom istraživanju tijekom natjecateljske sezone (Kronfeld i sur., 1977.). Nadalje, istraživanje je dokazalo kako koncentracije uree, kreatinina, bilirubina, eritrocita, amilaze i alkalne fosfataze ne ukazuje na promjene $u$ funkciji jetre ili bubrega, bez obzira na visok udio bjelančevina u obroku te se smatra kako korištenjem obroka s dostatnim udjelom bjelančevina, udio masti može ostati razmjeno visok (omjer bjelančevine : masti na bazi ST u omjeru višem od $1: 1$ ), dok se omjer manji od 1 mora koristiti uz oprez (Kronfeld i sur., 1977., FEDIAF, 2018.). Korištenje LCT dijete $u$ pravom smislu u prehrani pasa i mačaka, gdje je udio energije masti 3-4 puta veći od udjela energije dobive- nog iz bjelančevina i ugljikohidrata nije znanstveno potvrđeno, iako se njegova primjena promovira putem nerecenzirane literature: knjiga i članaka.

\section{Ketogena dijeta na temelju srednjelančanih triglicerida}

Ketogena MCT dijeta osmišljena je kako bi unaprijedila nedostatke klasične LCT dijete. Osnovne masne kiseline koje se koriste u MCT-u su kaprilna i dekanska kiselina te $u$ nešto manjem omjeru kapronska (heksanska) i laurinska kiselina. MCT dijeta, za razliku od LCT dijete, ne bazira se na omjerima makronutrijenata već kalorijama koje potječu od navedenih masnih kiselina s ciljem stvaranja ketonskih tijela (Liu i Wang, 2013.). MCT ketogena dijeta jedina je ketogena dijeta koja bilježi svoju primjenu $u$ veterinarskoj medicini, točnije $u$ hranidbi pasa (Law i sur., 2015.). Osnovna prednost MCT dijete je bolja apsorpcija i brži transport masnih kiselina $u$ jetru, a posljedično tome i brža $\beta$-oksidacija te nastanak ketonskih tijela (Giordano i sur., 2014.). Suprotno tomu, dugolančani trigliceridi karakteristični za LCT oblik dijete transportiraju se putem ductus thoracicus u obliku hilomikrona do krvi. Nadalje, za ulazak dugolančanih triglicerida $\mathrm{u}$ mitohondrije, $\mathrm{u}$ kojima se odvija proces $\beta$-oksidacije, potreban je karnitin kao nosač. Iz navedenog slijedi da je metabolizam dugolančanih triglicerida $\mathrm{u}$ odnosu na metabolizam srednjelančanih triglicerida sporiji te iziskuje više energije pa je tako prilikom korištenja srednjelančanih triglicerida, tj. MCT oblika ketogene dijete potrebno manje masti kako bi se postigla određena koncentracija ketonskih tijela i samo stanje ketoze. Također, manji udio masti i samim time veći udio bjelančevina i ugljikohidrata doprinosi većoj palatabilnosti obroka (Giordano i sur., 2014.). 


\section{Metabolizam u tumorskim stanicama}

Obilježje gotovo svih tumorskih stanica je promijenjen metabolički fenotip, koji uključuje promjenu metabolizma od staničnog disanja prema glikolizi, neovisno o dostupnosti kisika (Warburg i sur., 1927.). Warburgov efekt ili aerobna glikoliza podrazumijeva nastanak laktata iz glukoze, redukcijom piruvata $\mathrm{u}$ aerobnim uvjetima tzv. „aerobna fermentacija" kako bi se naglasila neobična proizvodnja laktata u aerobnim uvjetima (Pedersen, 2007.) (Slika 2.). Zdrave stanice $u$ mitohondrijima metaboliziraju piruvat dobiven glikolizom putem ciklusa limunske kiseline. Suprotno tome, tumorske stanice uglavnom koriste piruvat za nastanak laktata, putem mliječno-kiselog vrenja. $\mathrm{Na}$ taj način nastaje više ugljikovih spojeva, koji se kasnije koriste za sintezu makromolekula i pospješuju proliferaciju tumora (Van Der Heiden i sur.,
2009.). Dodatno, zaobilazi se oksidativni metabolizam u mitohondrijima i nastanak reaktivnih vrsta kisika (ROS). Time se pospješuje preživljavanje tumorskih stanica, budući da su one u odnosu na zdrave stanice osjetljivije na medijatore koji aktiviraju apoptozu posredovanu reaktivnim vrstama kisika. $\mathrm{Na}$ kraju, pojačanim iskorištavanjem glukoze nastaje kisela sredina koja pospješuje invazivnost i prodiranje tumorskih stanica u okolno tkivo (Peppicelli i sur., 2014.). Otto Warburg prvi je pretpostavio da tumori nastaju kao posljedica nedostatnog staničnog disanja, tj. oštećenog metabolizma mitohondrija (Pedersen, 2007.). Taj neprirodan oblik bioenergetike i ovisnost o glukozi postali su obilježje karcinoma. Konverzija piruvata u laktat stvara kisele uvjete $u$ mikrookolišu tumora i tako olakšava invaziju i metastaziranje (Stern i sur., 2002.). Iz navedenog proizlazi da rast, proliferacija, tvorba energije i transformacija tumorskih stanica uvelike ovise
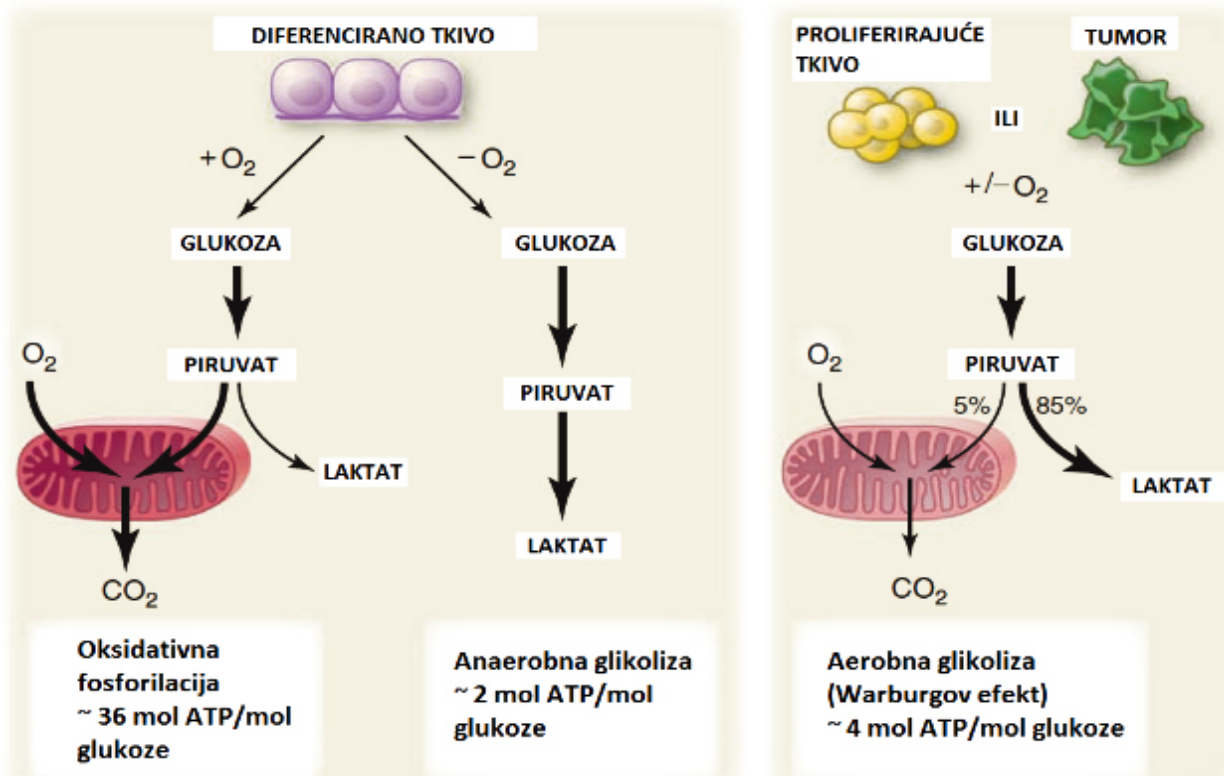

Slika 2. Warburgov efekt; prema: Van Der Heiden i sur. (2009.) 
o dostupnosti glukoze. Osnovna pretpostavka primjene ketogene dijete kod onkoloških pacijenata je da zbog specifičnosti metabolizma tumorskih stanica te njihove nemogućnosti prilagodbe i genomske nestabilnosti, ketogena dijeta omogućuje njihovo selektivno izgladnjivanje $\mathrm{u}$ odnosu na zdrave stanice koje mogu metabolizirati ketonska tijela (Seyfried i sur., 2014.).

Osim glukoze, glutamin je prepoznat kao značajan izvor energije mnogih tumorskih stanica (Seyfried i sur. 2014.). Dodatno, utvrđeno je kako je obilježje svih tumorskih stanica njihova mitohondrijska abnormalnost čime se remeti metabolički put dobivanja energije kroz proces oksidativne fosforilacije (Seyfried i sur., 2014.). Naime, struktura mitohondrija usko je povezana $s$ njihovom funkcijom te je dokazano kako se ultrastruktura mitohondrija u tumorskim stanicama znatno razlikuje od one $u$ zdravim stanicama (Seyfried i sur., 2014.). U tumorima visokog stupnja malignosti u glodavaca i in vitro staničnim kulturama, smanjeno je iskorištavanje masnih kiselina do 85 \% (Ristow, 2006.).

\section{Makronutrijenti u prehrani pasa i mačaka s tumorom}

Prema trenutnim preporukama, udio proteina $\mathrm{u}$ obroku $\mathrm{u}$ suhoj tvari trebao bi biti između 40 i $50 \%$, a udio probavljivih ugljikohidrata u ST najviše $25 \%$. Zbog sklonosti tumorskih stanica iskorištavanju probavljivih ugljikohidrata i proteina, masti ostaju dostupan izvor energije za domaćina zbog čega se za pse i mačke s tumorom preporuča davati hranu s većim udjelom masti (25-40\% masti u ST), većim udjelom omega-3 masnih kiselina $(>5,0 \%$ ST) te omjerom omega-6 i omega-3 masnih kiselina približno 1:1 (Mauldin, 2012.). Većina pasa i mačaka može tolerirati do $65 \%$ ukupnih energetskih potreba u obliku masti (do $42 \%$ na bazi ST), sve dok im se omogući period prilagodbe (Remillard i sur., 2000.). Ipak, budući da klinički znaci pojave pankreatitisa mogu nastati kod prehrane pasa i mačaka obrocima s visokim udjelom masnoće, ketogena dijeta trebala bi se primjenjivati soprezom, posebice u životinja s povećanim rizikom od razvoja pankreatitisa i u pretilih pasa i mačaka. Ukoliko se koristi obrok s visokim udjelom masti ključno je da udio bjelančevina u obroku bude $\mathrm{u}$ istovjetnom ili višem udjelu (FEDIAF, 2018.). Ukoliko su prisutne kontraindikacije za korištenje navedenog omjera makronutrijenata poput patologije bubrega, jetre ili sklonost pankreatitisu kod obje vrste, ključno je prilagoditi omjere.

\section{Individualna prilagodba obroka}

Prilikom izrade režima prehrane, valja uzeti u obzir upalna stanja, katabolizam i hiperglikemiju koji mogu biti prisutni (Saker i Selting, 2010.). U slučajevima kada je indicirana promjena prehrane, kada je obrok koji se do tada koristio, neprikladan, nekoliko čimbenika se koristi u odluci o najboljem obroku za određenu životinju no raspodjela kalorija dobivenih iz bjelančevina, masti i ugljikohidrata je jedan od najvažnijih (Slika 3.). Međutim, iako se u dijetetici životinja s neoplazijama možemo ravnati prema smjernicama bitno je uzeti u obzir razliku između vrsta, dobi, kliničkoj slici i prognozi te pojedinim specifičnostima poput preferencije pacijenta i mogućnost vlasnika da provodi pojedini hranidbeni režim. Stoga nije moguće preporučiti istovjetan obrok ili tip obroka koji bi pružio optimalnu prehranu u svim slučajevima (Mauldin, 2012.). Svaka životinja treba proći temeljitu i standardiziranu nutritivnu procjenu nakon čega se daju individualne hranidbene preporuke. Hranjenje obrokom pripremljenim kod kuće, dobar je izbor u slučaju gdje je prisutno odbijanje komercijalnog obroka i nedostatan 


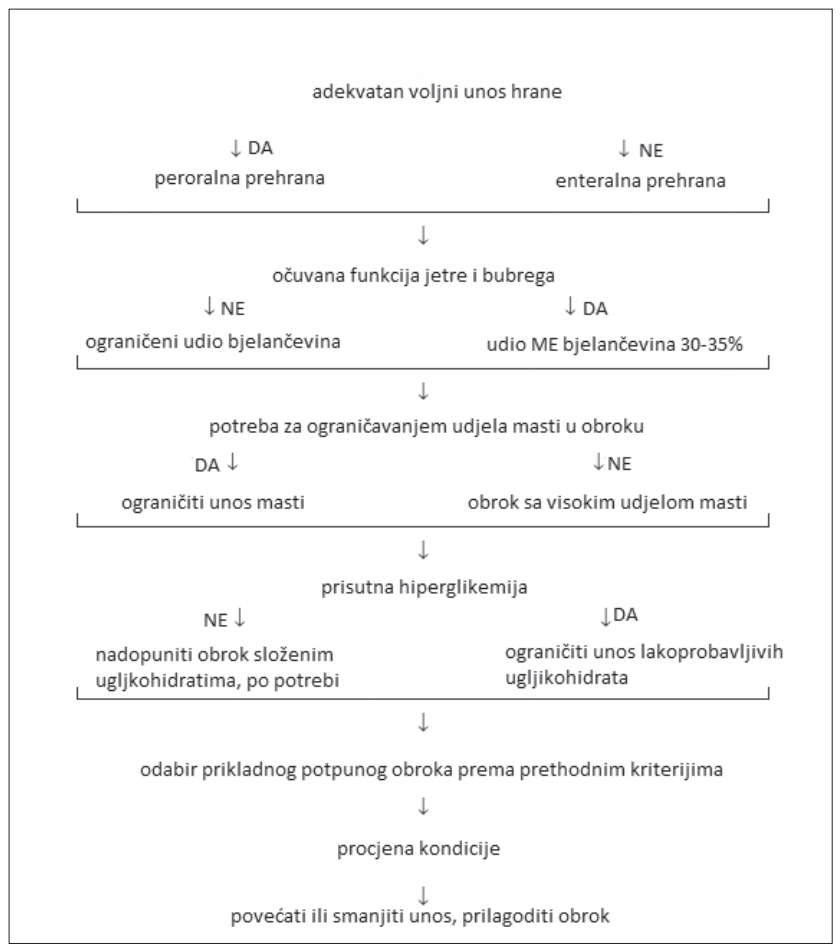

Slika 3. Algoritam odabira prikladnog hranidbenog režima na temelju udjela makronutrijenata u psa ili mačke s tumorom; prema: Mauldin (2012.).

dnevni kalorijski unos pri čemu je cilj povećati palatabilnost i unos hrane. Vlasnicima su dostupni su brojni nerecenzirani izvori koji sadrže objavljene recepture za izradu obroka, no vrlo je bitno naglasiti da obroci pripremljeni kod kuće moraju biti usklađeni sa smjernicama izdanim od strane NRC-a i prilagođeni kliničkoj slici i hranidbenom statusu životinje (NRC, 2006.).

\section{Tumorska kaheksija}

Do danas, ocjena tjelesne kondicije i promjene tjelesne mase pasa i mačaka, najpraktičnije su metode procjene nutritivnog režima. Iako nije ustvrđena direktna povezanost stupnja tumora i nutritivnog statusa uključujući kaheksiju, smatra se da agresivniji tumori imaju jači utjecaj na tjelesnu kondiciju. Su- protno tome, čak i benigni tumori mogu znatno utjecati na nutritivni status pasa i mačaka ako remete unos hrane (Saker i Selting, 2010.). Životinje mogu razviti odbojnost prema hrani iz razloga što je došlo do promijene u osjetu okusa i mirisa prouzročenih terapijom (Ogilvie i Vail, 1992.). Velik gubitak tjelesne mase onkološkog pacijenta naziva se tumorska kaheksija, sindrom klinički karakteriziran gubitkom tjelesne mase, mučninom, anemijom te gubitkom mišićne mase i masnih zaliha (Ogilvie i Vail, 1992.). Neovisno o tipu tumora, tumorska kaheksija ima negativan učinak na kvalitetu života i prognozu (Ogilvie i Vail, 1992.). Razlog nastanka tumorske kaheksije djelomično može biti negativni energetski status, nastao kao posljedica smanjenog unosa ili promijenjene potrošnje energije ili lošeg podnošenja 
terapije (Tisdale, 2009.). Poznato je kako je optimalna ocjena tjelesne kondicije $u$ korelaciji s prognozom i vremenom preživljavanja (Baez i sur., 2007.). Iako su ocjena tjelesne kondicije i promjena tjelesne mase dobri klinički pokazatelji, ne uzimaju u obzir složenost čimbenika koji utječu na pojavu kaheksije, poput metaboličkih promjena koje se javljaju prije očitih kliničkih znakova (Ogilvie i Vail, 1990.). Hospitalizirani pacijenti trebali bi unositi dovoljno hrane da zadovolje uzdržne potrebe, a ukoliko to nije moguće tijekom tri ili više dana, potrebno je uvesti enteralnu ili parentaralnu prehranu s ciljem održavanja optimalne ocjene tjelesne kondicije. Agresivni protokoli za gubitak tjelesne mase su kontraindicirani $u$ pretilih pacijenata. Naime, opsežna kalorijska restrikcija može doprinijeti razvoju klinički znatnog stupnja pothranjenosti, hipoproteinemije, gubitka nemasne tjelesne mase, produljenom cijeljenju rana, imunosupresiji i kompromitiranoj funkciji organa. Sindrom anoreksije i kaheksije onkoloških pacijenata povezuje se s intenzivnim metaboličkim promjenama, uključujući pojačanu proteolizu mišića, stoga su smanjena mišićna masa i povećana potreba za bjelančevinama $\mathrm{u}$ onkoloških pacijenata prouzročene preraspodjelom aminokiselina za potrebe sinteze jetrenih reaktivnih proteina akutne faze, podršku staničnom imunološkom odgovoru i opskrbom glukoneogeneze supstratima (Ogilvie i Vail 1990.).

\section{Zaključna razmatranja}

Iz razloga što do danas nije provedeno istraživanje koje bi ukazalo na moguću primjenu MCT ili LCT dijete, u pasa i mačaka s tumorima nije moguće sa sigurnošću tvrditi koji su rizici i prednosti takvog hranidbenog pristupa. Iako postoje mnogobrojni dokazi $\mathrm{u}$ istraživanjima provedenim na laboratorijskim životinjama i ljudima, navedeni rezultati i smjernice moraju se uzeti sa zadrškom zbog opsežnih metaboličkih razlika između vrsta. Naime, razlika među vrstama, pas i čovjek, vidljiva je u brzini razvoja i intenzitetu ketonemije, koja se u ljudi javlja znatno brže i dostiže značajno više vrijednosti u usporedbi s psima, no nije dokazana razlika $\mathrm{u}$ metabolizmu ketonskih tijela u pasa i ljudi (Crandall, 1940.). Dodatno, izrazita sposobnost iskorištavanja ketonskih tijela u pasa otežava praćenje rezultata istraživanja. Međutim, obećavajući rezultati postignuti korištenjem MCT ketogene dijete $u$ pasa s epilepsijom ukazuju kako postoje temelji za provedbu istraživanja kojima bi se ustvrdila učinkovitost u onkoloških pacijenata: pasa i mačaka (Larsen i sur., 2014., Law i sur., 2015.). Iako je primjena ketogene dijete kao potporne terapije tumora te važnost metabolizma $u$ progresiji tumora, opetovano je dokazana $\mathrm{u}$ humanim istraživanjima do danas nije provedeno istraživanje koje bi potvrdilo blagotvorne učinke $\mathrm{u}$ pasa i mačaka $\mathrm{s}$ neoplazijama (Woolf i Scheck, 2015.). Pri izradi prehrambenog plana u onkoloških pacijenata ključno je prilagoditi oblik hranidbenog režima svakom pacijentu pojedinačno, uzimajući pritom $u$ obzir kliničku sliku, prognozu i prisutnost ostalih patologija koje će uvjetovati prilagodbe obroka.

\section{Literatura}

1. BAEZ, J. L., K. E. MICHAEL, K. SORENMO and F. S. SHOFER (2007): A prospective investigation of the prevalence and prognostic significance of weight loss and changes in body condition in feline cancer patients. J. Feline Med. Surg. 9, 411-417.

2. BLANCHARD, G., B. M. PARAGON, F. MILLIAT and C. LUTTON (2002): Dietary L-carnitine supplementation in obese cats alters carnitine metabolism and decreases ketosis during fasting and induced hepatic lipidosis. J. Nutr. 132, 204-210.

3. BONNET, B. N., A. EGENVALL, A. HEDHAMMAR and P. OLSON (2005): Mortality in over 350,000 insured Swedish dogs from 1995-2000: I. Breed-, gender-, age- and cause-specific rates. Acta Vet. Scand. 46, 105-120. 
4. BUTTERWICK, R. F., C. SALT and T. D. WATSON (2012): Effects of increases in dietary fat intake on plasma lipid and lipoprotein cholesterol concentrations and associated enzyme activities in cats. Am. J. Vet. Res. 73, 62-67.

5. CRANDALL, L. A. (1940): A comparison of ketosis in man and dog. J. Biol. Chem. 138, 123-128.

6. DE BRUIJNE, J. J. and W. E. VAN DEN BROM (1985): The effect of long-term fasting on ketone body metabolism in the dog. Comp. Biochem. Physiol. 2, 391-395.

7. DE BRUIJNE, J., J. N. ALTSZULER, J. HAMPSHIRE, T. J. VISSER and W. H. L. HACKENG (1981): Fat mobilisation and plasma hormone levels in fasted dogs. Metabolism 30, 190-194.

8. EGENVALL, A., B. N. BONNET, A. HEDHAMMAR and P. OLSON (2005): Mortality in over 350,000 insured Swedish dogs from 1995-2000: II. Breedspecific age and survival patterns and relative risk for causes of death. Acta Vet. Scand. 46, 121-136.

9. EISERT, R. (2011): Hypercarnivory and the brain: protein requirements of cats reconsidered. J. Comp. Physiol. 181, 1-17.

10. EL BACHA, T., M. LUZ and A. DA POIAN (2010): Dynamic Adaptation of Nutrient Utilization in Humans. Nature Ed. 3, 8.

11. EUROPEAN PET FOOD INDUSTRY FEDERATION (FEDIAF) (2017): Nutritional Guidelines for complete and complementary pet food for cats and dogs. FEDIAF, Brussels, Belgija.

12. GIORDANO, C., M. MARCHIÒ, E. TIMOFEEVA and G. BIAGINI (2014): Neuroactive peptides as putative mediators of antiepileptic ketogenic diets. Front. Neurol. 5, 63.

13. KELLER, C., A. LIESEGANG, D. FREY and B. WICHERT (2017): Metabolic response to three different diets in lean cats and cats predisposed to overweight. BMC Vet. Res. 13, 184

14. KRONFELD, D. S., E. P. HAMMEL, C. F. RAMBERG, JR. and H. L. DUNLAP, JR. (1977): Hematological and metabolic responses to training in racing sled dogs fed diets containing medium, low, or zero carbohydrate. Am. J. Clin. Nutr. 30, 419-430.

15. LARSEN, J. A., T. J. OWENS and A. J. FASCETTI (2014): Nutritional management of idiopathic epilepsy in dogs. J. Am. Vet. Med. Assoc. 245, 504-508.

16. LAW, T. H., E. S. DAVIES, Y. PAN, B. ZANGHI, E. WNT and H. A. VOLK (2015): A randomised trial of a medium-chain TAG diet as treatment for dogs with idiopathic epilepsy. Br. J. Nutr. 114, 1438-1447.

17. LESTER, T., G. CZARNECKI-MAULDEN and D. LEWIS (1999): Cats increase fatty acid oxidation when isocalorically fed meat-based diets with increasing fat content. Am. J. Physiol. 277, 878-886.

18. LINDSAY, S., C. ENTENMAN and I. L. CHAIKOFF (1948): Pancreatitis accompanying hepatic disease in dogs fed a high fat, low protein diet. Arch. Pathol. 45, 635-638.

19. LIU, Y. M. and H. S., WANG (2013): Medium-chain triglyceride ketogenic diet, an effective treatment for drug-resistant epilepsy and a comparison with other ketogenic diets. Biomed. J. 36, 9-15.

20. MAULDIN, G. E. (2012): Nutritional Management of Oncological Diseases. In: Applied Veterinary Clinical Nutrition, Wiley-Blackwell, Ames, Iowa (315-327).

21. NATIONAL RESEARCH COUNCIL (2006): Nutrient Requirements of Dogs and Cats. Washington, DC: The National Academies Press.

22. NEAL, E. G., H. CHAFFE, R. H. SCHWARTZ, M. S. LAWSON, N. EDWARDS, G. FITZSIMMONS, A. WHITNEY and J. H. CROSS (2008): The ketogenic diet for the treatment of childhood epilepsy: a randomised controlled trial. Lancet. Neurol. 7, 500-506.

23. OGILVIE, G. K. and D. M. VAIL (1990): Advances in nutritional therapy for the cancer patient. Vet. Clin. North Am. Small Anim. Pract. 20, 969-985.

24. OGILVIE, G. K. and D. M. VAIL (1992): Unique metabolic alterations associated with cancer cachexia in the dog. In: Current Veterinary Therapy XI., WB Saunders Co, Philadelphia (433-438).

25. PEDERSEN, P. L. (2007): Warburg, me and hexokinase 2: multiple discoveries of key molecular events underlying one of cancers' most common phenotypes, the "Warburg Effect", i.e., elevated glycolysis in the presence of oxygen. J. Bioenerg. Biomembr. 39, 211-222.

26. PEPPICELLI, S., F. BIANCHINI and L. CALORINI (2014): Extracellular acidity, a "reappreciated" trait of tumor environment driving malignancy: perspectives in diagnosis and therapy. Cancer. Metastasis. Rev. 33, 823-832.

27. POFF, A. M., C. ARI, P. ARNOLD, T. N. SEYFRIED and D. P. D'AGOSTINO (2014): Ketone supplementation decreases tumor cell viability and prolongs survival of mice with metastatic cancer. Int. J. Cancer 135, 1711-1720.

28. PUCHOWICZ, M. A., C. L. SMITH, C., BOMONT, J. KOSHY, F. DAVID and H. BRUNENGRABER (2000): Dog model of therapeutic ketosis induced by oral administration of R,S-1,3-butanediol diacetoacetate. J. Nutr. Biochem. 11, 281-287.

29. REMILLARD, R. L., P. J. AMSTRONG and D. J. DAVENPORT (2000): Assisted feeding in hospitalized patients: Enteral and parenteral nutrition. In: Small Animal Clinical Nutrition, Fourth Edition, Mark Morris Institute, Topeka (351-399).

30. RISTOW, M. (2006): Oxidative metabolism in cancer growth. Curr. Opin. Clin. Nutr. Metab. Care 9, 339-345.

31. SAKER, K. E. and K. A. SELTING (2010): Cancer. In: Small Animal Clinical Nutrition, Fifth Edition, Mark Morris Institute, Topeka (587-607).

32. SEYFRIED, T. N., R. E. FLORES, A. M. POFF and D. P. D'AGOSTINO (2014): Cancer as a metabolic disease: implications for novel therapeutics. Carcinogenesis 35, 515-527.

33. SNYDER, L. A., E. R. BERTONE, R. M. JAKOWSKI, M. S. DOONER, J. JENNINGS-RITCHIE and A. S. MOORE (2004): p53 expression and environmental 
tobacco smoke exposure in feline oral squamous cell carcinoma. Vet. pathol. 41, 209-214.

34. STERN, R., S. SHUSTER, B. A. NEUDECKER and B. FORMBY (2002): Lactate stimulates fibroblast expression of hyaluronan and CD44: the Warburg effect revisited. Exp. Cell. Res. 276, 24-31.

35. TISDALE, M. J. (2009): Mechanisms of cancer cachexia. Physiol. Rev. 89, 381-410.

36. VAN DER HEIDEN, M. G., L. C. CANTLEY and C. B. THOMPSON (2009): Understanding the Warburg effect: the metabolic requirements of cell proliferation. Science 324, 1029-1033.
37. WARBURG, O., F. WIND and E. NEGELEIN (1927): The Metabolism of Tumors in the Body. J. Gen. Physiol. 8, 519-530.

38. WESTMAN, E. C., W. S. YANCY, JR. J. C. MAVROPOULOS, M. MARQUART and J. R. McDUFFIE (2008): The effect of a lowcarbohydrate,ketogenic diet versus a low-glycemic indeks diet on glycemic control in type 2 diabetes mellitus. Nutrition \& Metabolism 5, 36.

39. WOOLF, E. C. and A. C. SCHECK (2015): The ketogenic diet for the treatment of malignant glioma. J. Lipid. Res. 56, 5-10.

\section{Ketogenic diet in small animal oncology patients}

Diana BROZIĆ, DVM, PhD, Assistant Professor, Hrvoje VALPOTIĆ, DVM, PhD, Associate Professor, Nino MAĆEŠIĆ, DVM, PhD, Associate Professor, Marko SAMARDŽIJA, DVM, PhD, Full Professor, Faculty of Veterinary Medicine, Croatia; Helena HAJDIN, DVM, Varaždin, Croatia

Recent studies indicate that the metabolism of tumour cells is characterized by changes in energy production through oxidative phosphorylation and fermentation, and it is presumed that their growth and development can be controlled by altering the energy substrate. Tumour cells have increased glucose consumption, even in aerobic conditions, most likely due to mitochondrial dysfunction, with increased glycolysis as a compensatory response. Therefore, dietary changes, such as a ketogenic high fat, medium protein and low carbohydrate diet, which induces oxidative metabolism while limiting glucose consumption, represents a possible nutritional approach causing selective metabolic stress of tumour cells. Nonetheless, the use of the ketogenic diet in human research has repeatedly proven to have beneficial effects. However, the use of a ketogenic diet in dogs and cats as in nutritional management during treatment or recovery in tumour patients has not been described in the existing veterinary scientific literature. The use of the MCT diet in epileptic dogs provided promising results. Adaptive metabolic mechanisms in cats and dogs through the effective clearance of ketone bodies and fast adaptation to fatty acids as the main energy substrate implies that there is a basis for the use of the ketogenic diet in small animal oncology patients. Nevertheless, without research to support this, it is presumptive to claim that the use of a ketogenic diet is without risk. According to the existing guidelines, the dietary plan for small animal oncology patients should include an individually adapted nutrition plan, with consideration of the clinical symptoms, prognosis, and concurrent pathologies.

Key words: ketogenic diet; tumour; dog; cat 